\title{
Originals
}

\section{Rat amylin mediates a pressor response in the anaesthetised rat: implications for the association between hypertension and diabetes mellitus}

\author{
J.M. H aynes ${ }^{1}$, W. C. H odgson ${ }^{2}$, M .E . Cooper ${ }^{1}$ \\ ${ }^{1}$ Department of Medicine, University of Melbourne, Austin and Repatriation Medical Centre (Repatriation Campus), Victoria, \\ Australia \\ ${ }^{2}$ Department of Pharmacology, Monash University, Clayton, Victoria, Australia
}

Summary Amylin (or islet amyloid polypeptide) has been reported to have binding sites in the central nervous system and the kidney and has been shown to activate plasma renin. It has been postulated that this peptide may be an important mechanistic link between hypertension and diabetes in the insulin resistance syndrome. To explore this issue, the effects of rat amylin on mean arterial blood pressure were investigated in anaesthetised rats. Amylin elicited a pressor response of approximately $10 \mathrm{mmHg}$ (maximal at $100 \mathrm{pmol} \cdot \mathrm{kg}^{-1}$ ) which was apparent within 30-60 s and persisted over $15 \mathrm{~min}$. At higher concentrations amylin elicited a hypotensive response (negative $\log \mathrm{IC}_{50} 8.52 \mathrm{~mol} \cdot \mathrm{kg}^{-1}$ ). The novel amylin receptor antagonist AC413 $\left(12 \mathrm{nmol} \cdot \mathrm{kg}^{-1} \cdot \mathrm{min}^{-1}\right)$ reduced the pressor response but not the hypotensive effects of amylin. The peptide antagonist calcitonin gene-related peptide $(\mathrm{CGRP})_{8-37}\left(12 \mathrm{nmol} \cdot \mathrm{kg}^{-1}\right.$. $\min ^{-1}$ ) reduced the pressor response elicited by amylin and also antagonized the hypotensive effect of amylin. Pre-treatment of animals with the ganglion blocker mecamylamine $\left(3 \mathrm{mg} \cdot \mathrm{kg}^{-1}\right.$ s.c.) reduced the pressor effect of amylin. Following the administration of the angiotensin converting enzyme inhibitor ramiprilat $\left(300 \mathrm{nmol} \cdot \mathrm{kg}^{-1}\right.$ i.v. $)$ the pressor response to amylin was reduced. Salmon calcitonin also elevated blood pressure in the anaesthetised rat; doses of amylin and salmon calcitonin associated with a pressor effect were associated with increases in plasma renin activity. We conclude that amylin may act centrally to elevate blood pressure in the anaesthetised rat, possibly through activation of the renin angiotensin system. [Diabetologia (1997) 40: 256-261]

Keywords Amylin, hypertension, calcitonin, ACE inhibition, calcitonin gene related peptide.
Amylin, or islet amyloid polypeptide, is a 37-amino acid hormone secreted by the pancreas $[1,2]$. Previously reported actions of this peptide include the regulation of insulin secretion [3] and the inhibition of glucose uptake [4]. Amylin shares a high degree of sequence homology (approximately $50 \%$ ) with calcitonin gene-related peptide (CGRP) and both of these

Received: 1 July 1996 and in revised form: 26 September 1996

Corresponding author: Associate Professor M.E. Cooper, Department of Medicine, University of Melbourne, Austin and Repatriation Medical Centre (Repatriation Campus), Heidelberg West, Victoria 3081, Australia

A bbreviations: CGRP, Calcitonin gene-related peptide; ACE, angiotensin converting enzyme; MAP, mean arterial pressure; sCT, salmon calcitonin; PRA, plasma renin activity. peptides elicit marked hypotension in rats [5-8]. The hypotensive action of amylin is blocked by the CGRP antagonist fragment, $\mathrm{CGRP}_{8-37}[6]$ and is consequently thought to be mediated through vascular CGRP-receptors. Although rat amylin and salmon calcitonin share little sequence homology, there is evidence that these peptides compete with high affinity for a single class of binding sites in regions of the rat brain [9-11]. Furthermore, calcitonin also shares some physiological effects with both CGRP and amylin. For example all three peptides have been shown to increase plasma renin activity in either man [12$14]$ or rats [15].

In the present study we investigated the effects of amylin and salmon calcitonin on arterial blood pressure in the anaesthetised rat. In addition, we have used the novel amylin receptor-selective peptide 
antagonist, AC413 [15], and the inactive peptide fragment, $\mathrm{CGRP}_{8-37}$ which acts as an amylin antagonist at relatively high concentrations [16]. Since amylin-selective binding sites have been found in rat brain [911] and kidney [15] and amylin has also been shown to activate plasma renin activity in both rats [15] and humans [12] we have also investigated the effect of ganglion blockade and angiotensin-converting enzyme (ACE)-inhibition on the blood pressure response to amylin.

\section{Materials and methods}

A nimals. Male Sprague-Dawley rats (280-360 g) were housed with a photoperiod of $12 \mathrm{~h}$ light- $12 \mathrm{~h}$ dark at $20 \pm 1^{\circ} \mathrm{C}$. Animals were allowed access to water and food (GR2 pellets; ClarkKing and Co., Melbourne, Australia) ad libitum. On the day of use the animals were anaesthetised with urethane (1.3$1.5 \mathrm{~g} \cdot \mathrm{kg}^{-1}$ i.p.) and the depth of anaesthesia was monitored with paw pinch and corneal reflex tests. Animals were placed on a heated table and body temperature monitored continuously and maintained between 35 and $37^{\circ} \mathrm{C}$. Both the left jugular and carotid arteries were cannulated with polyethylene catheters (SP37 Dural plastics, Auburn, Australia). The jugular cannula was flushed with heparin (500 U per rat) and the preparations allowed at least 3 min to equilibrate. Agonists or vehicle (Haemaccel; Behring, Frankfurt, Germany) were added as a bolus (less than $0.15 \mathrm{ml}$ over $10 \mathrm{~s}$ ) into the jugular cannula at approximately 20-min intervals. Changes in arterial pressure were monitored $\left(10\right.$ samples $\left.\cdot \mathrm{s}^{-1}\right)$ via Gould-Statham (model P-23, Cleveland, Ohio, USA) or disposable (model 43-212 Baxter Healthcare Round Lake, IL, USA) pressure transducers coupled to a MacLab/8 data acquisition system (AD Instruments, Castle Hill, N. S. W., Australia).

Drugs used included rat amylin (Bachem, Torrance, California, USA, AC413 [a chimera of rat amylin and salmon calcitonin, ATQRLANFLVRLQTYPRTNVGANTY], Amylin Corporation, San Diego, Calif., USA), human angiotensin I (Auspep, Melbourne, Australia), rat CGRP $_{8-37}$ (Amylin Corporation), atropine sulphate (Astra Pharmaceuticals, Abbotsford, Australia), ramiprilat (Hoechst, Frankfurt, Germany) rat $\alpha$-CGRP (Bachem), rat calcitonin (Bachem), mecamylamine $\mathrm{HCl}$ (Sigma Chemical Co., St. Louis, Mo., USA), phenylephrine (Sigma Chemical Co.) and salmon thyrocalcitonin (Sigma Chemical Co.). All drugs were made up in vehicle on the day of use.

Antagonists or vehicle were infused at $7 \mu \mathrm{l} \cdot \mathrm{min}^{-1}$ (Razel model A-99 syringe pump, Razel, Stamford, CT, USA) into the jugular cannula for $60 \mathrm{~min}$ prior to the addition of agonists. Antagonists were continuously infused into animals for a further $3 \mathrm{~h}$. No animal received more than one agonist. In a separate series of experiments, plasma renin activity (PRA) was measured in anaesthetised rats 5 min after administration of vehicle, rat amylin or salmon calcitonin. PRA was assessed as generation of angiotensin I as measured by radioimmunoassay [17]. Mean arterial pressure (MAP) was calculated over $10 \mathrm{~s}$ periods. Peak changes in MAP were used for analysis and defined as the greatest increase in MAP occurring within 5 min of addition of the agonist.

$\mathrm{G}$ anglion blockade. One group of rats were ganglion blocked with mecamylamine $\left(3 \mathrm{mg} \cdot \mathrm{kg}^{-1}\right.$, s.c.), given atropine $\left(0.4 \mathrm{mg} \cdot \mathrm{kg}^{-1}\right.$, s.c.) $[18,19]$ and allowed to equilibrate for $30 \mathrm{~min}$ prior to the addition of agonists. In an additional group of ganglion blocked rats, MAP was raised with a constant infusion of phenylephrine $\left(60 \mathrm{nmol} \cdot \mathrm{kg}^{-1} \cdot \mathrm{min}^{-1} \mathrm{i}\right.$. v. $)$.

ACE -inhibition. The ACE inhibitor, ramiprilat (300 $\mathrm{nmol} \cdot \mathrm{kg}^{-1}$ i. v. bolus), was administered to rats and $10 \mathrm{~min}$ later the effects of agonists or of angiotensin I were tested. This dose of ramiprilat was sufficient to reduce the pressor response to angiotensin I $\left(100 \mathrm{mg} \cdot \mathrm{kg}^{-1}\right)$ by $80 \%$ for at least $120 \min (\mathrm{n}=5)$ [20].

\section{Statistical analysis}

Changes in MAP following the administration of antagonists, ramiprilat or mecamylamine were analysed using a paired $\mathrm{t}$ test (Statview SE and Graphics, Brainpower, Calabasas, California, USA). Responses to each concentration of amylin were compared (Student's t-test) to equivalent vehicle-only time controls. Hypotensive response data were analysed using FLEXIFIT to provide estimates of $\mathrm{IC}_{50}$ and potency ratios $[21,22]$. Differences between the pressor effect of amylin in the control and treatment groups were compared by use of a one-way analysis of variance (Statview SE and Graphics). Further analysis, due to multiple comparisons, was performed using the Fisher Least Significance Difference (PLSD) method (Statview SE and Graphics). A p-value less than 0.05 was considered statistically significant. Results for changes in MAP are expressed as mean \pm SEM.

\section{Results}

A naesthetised rats. Following anaesthesia with urethane $\left(1.3 \mathrm{~g} \cdot \mathrm{kg}^{-1}\right.$ i.p.) preparations were stable for approximately $3 \mathrm{~h}$ with MAP of $90 \pm 4 \mathrm{mmHg}$ and heart rate of $344 \pm 4$ beats $\cdot \mathrm{min}^{-1}$.

E ffect of agonists. Compared to vehicle-only time controls both amylin and salmon calcitonin (sCT) elicited significant pressor effects at 10 and 100 pmol $\cdot \mathrm{kg}^{-1}(p<0.05$, see Fig. 1 for typical changes in MAP and Fig. 2). The effects of amylin on blood pressure were apparent within 30 to $60 \mathrm{~s}$ and persisted for up to 15 min (Fig. 1). Higher doses of amylin ( $>1$ nmol $\cdot \mathrm{kg}^{-1}$ ) reduced MAP (Fig. 2). The pressor effects of amylin and sCT were both quantitively and qualitatively similar $(0.1 \mathrm{nmol} / \mathrm{kg}$ amylin, $9.7 \pm$ $3.8 \mathrm{mmHg}, \mathrm{n}=6 ; 0.1 \mathrm{nmol} / \mathrm{kg} \mathrm{sCT}, 11.5 \pm 3.9 \mathrm{mmHg}$, $n=6)$, but were not additive $(n=6,8.8 \pm$ $2.7 \mathrm{mmHg})$. Rat calcitonin $\left(100 \mathrm{pmol} \mathrm{kg} \mathrm{kg}^{-1}\right)$ was without significant pressor activity $(n=6,2.2 \pm$ $3.5 \mathrm{mmHg}$ ).

E ffect of antagonists. The antagonists AC413 and $\mathrm{CGRP}_{8-37}\left(12 \mathrm{nmol} \cdot \mathrm{kg}^{-1} \cdot \mathrm{min}^{-1}\right)$ did not significantly alter basal MAP (data not shown). AC413 (12 nmol . $\left.\mathrm{kg}^{-1} \cdot \mathrm{min}^{-1}\right)$ significantly reduced the pressor effect of amylin (Fig. 3), but did not affect the hypotensive response to amylin (Table 1$)$. $\mathrm{CGRP}_{8-37}$ at a dose of $4 \mathrm{nmol} \cdot \mathrm{kg}^{-1} \cdot \mathrm{min}^{-1}$ did not affect either the maximum pressor or the hypotensive responses to amylin 


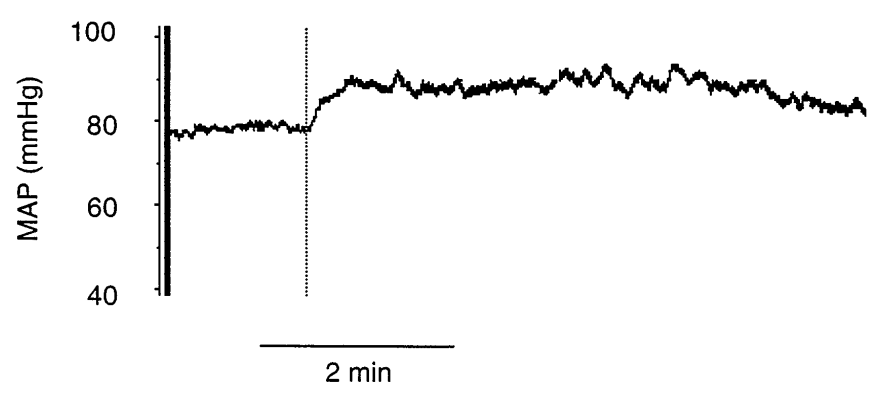

Fig. 1. A typical response to amylin $\left(10 \mathrm{pmol} \cdot \mathrm{kg}^{-1}\right.$ i.v. $)$ over $6 \mathrm{~min}$ in the anaesthetised rat. The vertical axis shows mean arterial pressure (MAP) $(\mathrm{mmHg})$. Amylin administration is indicated by the dotted line $(. .$.

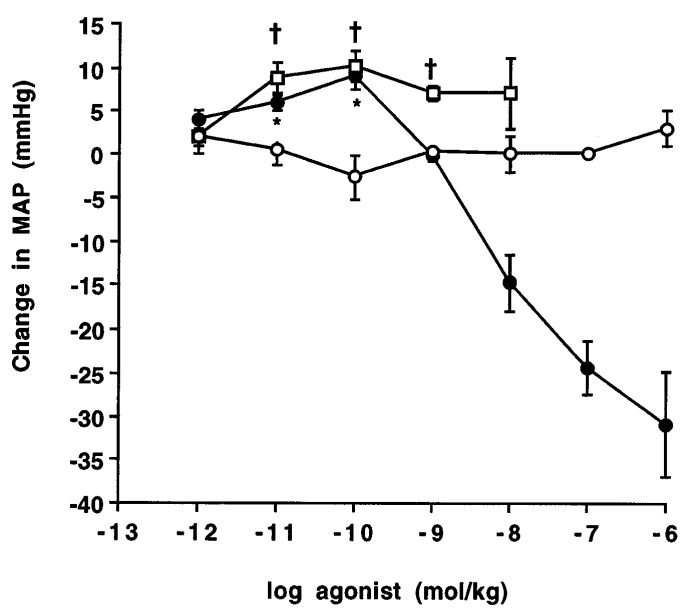

Fig. 2. Effects of amylin (O) and salmon calcitonin $(\square)$ on basal mean arterial pressure (MAP) in the anaesthetised rat. The vertical axes show the changes in MAP $(\mathrm{mmHg})$ which occurred within 5 min after the addition of agonist or vehicle (O). The horizontal axis shows the molar concentration of agonist or vehicle control. Each point shows the mean response ( \pm SEM) of $6-16$ animals. $* p<0.05$, amylin vs time control. $\dagger p<0.05$, salmon calcitonin vs time control

( $\mathrm{n}=5$, data not shown). At the higher concentration of $12 \mathrm{nmol} \cdot \mathrm{kg}^{-1} \cdot \mathrm{min}^{-1}, \mathrm{CGRP}_{8-37}$ significantly reduced the pressor effect of amylin (Fig. 3), and also significantly antagonized the hypotensive effects of amylin (Table 1).

Ganglion blockade. Following ganglion blockade with mecamylamine $\left(3 \mathrm{mg} \cdot \mathrm{kg}^{-1}\right.$ s.c.) and the addition of atropine $\left(0.4 \mathrm{mg} \cdot \mathrm{kg}^{-1}\right.$ s.c. $)$, MAP was significantly reduced from $82 \pm 8$ to $50 \pm 4 \mathrm{mmHg}$. The pressor effect of amylin was reduced compared with controls (Fig. 3). The $\mathrm{IC}_{50}$ of the hypotensive effect of amylin (Table 1) was not affected by ganglion blockade. In one group of ganglion-blocked animals phenylephrine $\left(60 \mathrm{nmol} \cdot \mathrm{kg}^{-1} \cdot \mathrm{min}^{-1}\right)$ was constantly infused to increase MAP (to $97 \pm 9 \mathrm{mmHg}$ ). In these animals the pressor effect of amylin was significantly reduced but the hypotensive effect of amylin was significantly enhanced (Table 1).

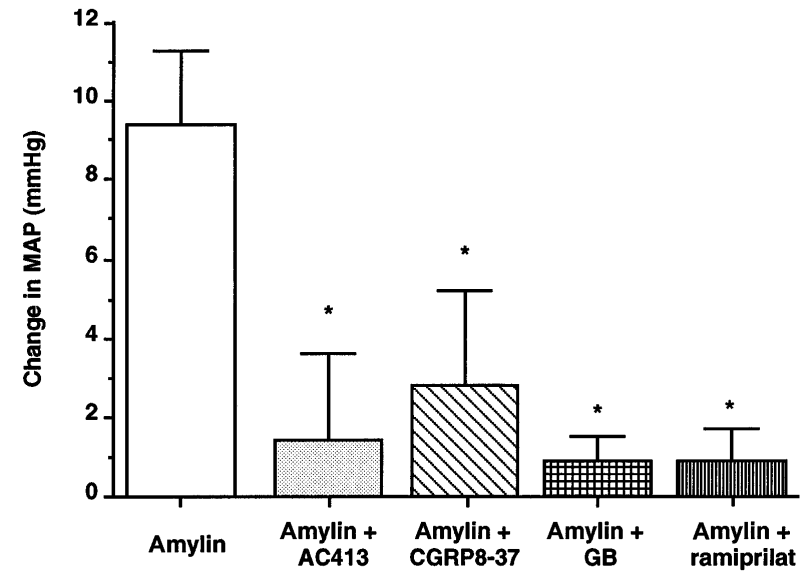

Fig. 3. Effects of peptide antagonists, ganglion blockade (GB) and angiotensin-converting enzyme (ACE)-inhibition on the pressor response to amylin. The vertical axis shows the maximal change in MAP occurring within 5 min following the addition of $10 \mathrm{pmol} / \mathrm{kg}$ rat amylin. Each column represents the mean \pm SEM of 6-9 replicate experiments. Peptide antagonists were infused at a rate of $12 \mathrm{nmol} \cdot \mathrm{kg}^{-1} \cdot \mathrm{min}^{-1}$. GB was achieved by subcutaneous preadministration of mececylamine $3 \mathrm{mg} / \mathrm{kg}$ and atropine $0.4 \mathrm{mg} / \mathrm{kg}$. Ramiprilat was infused at a bolus of $300 \mathrm{mg} / \mathrm{kg}$. * $\mathrm{p}<0.05$ vs amylin alone

ACE inhibition. The ACE inhibitor ramiprilat (300 $\mathrm{nmol} \cdot \mathrm{kg}^{-1}$ i.v.) significantly reduced basal MAP from $91 \pm 7$ to $65 \pm 6 \mathrm{mmHg}$. Following the administration of ramiprilat the pressor response to amylin was reduced (Fig.3). ACE inhibition did not affect the hypotensive action of amylin (Table 1). Ramiprilat also attenuated the pressor response to $\mathrm{sCT}$ $(2.2 \pm 2.8 \mathrm{mmHg}, \mathrm{n}=6, \mathrm{p}<0.05$ vs sCT alone $)$.

E ffects of agonists on plasma renin activity (PRA). We measured (PRA) in a subgroup of anaesthetised rats (Table 2). Vehicle was associated with no change in PRA whereas bolus administration of either amylin or $\mathrm{SCT}$ at a concentration of $1 \mathrm{nmol} / \mathrm{kg}$ which is associated with a pressor response was associated with an increase in PRA (Table 2).

\section{Discussion}

We have shown that rat amylin elicits a pressor response in anaesthetised rats. The pressor response to amylin is reduced by the peptide antagonists AC413 and $\mathrm{CGRP}_{8-37}$ and also by ganglion blockade and ACE inhibition. Blockade of this pressor effect with peptide antagonists suggests that this rise in blood pressure involves an interaction between amylin and its receptor. The presence of high affinity amylin binding sites in the brain has been previously reported and includes sites which would have access to blood-borne peptides [9]. Salmon calcitonin has also elicited a pressor response and is consistent with its ability to interact with the amylin binding site in the 
Table 1. Effects of peptide antagonists, ganglion blockade and angiotensin-converting enzyme (ACE)-inhibition on vasodilator response (negative $\log \mathrm{IC}_{50} \mathrm{~mol} \cdot \mathrm{kg}^{-1}$ ) to amylin in the anaesthetised rat

\begin{tabular}{ll}
\hline & Negative $\log \mathrm{IC}_{50}$ \\
\hline Control & $8.53 \pm 0.21$ \\
Ganglion blockade & $8.84 \pm 0.25$ \\
Ganglion blockade + & \\
phenylephrine & $9.14 \pm 0.23^{\mathrm{a}}$ \\
$\mathrm{CGRP}_{8-37}$ & $7.83 \pm 0.37^{\mathrm{a}}$ \\
AC413 & $8.69 \pm 0.22$ \\
ACE inhibition & $8.67 \pm 0.48$ \\
\hline
\end{tabular}

These values show the negative $\log \mathrm{IC}_{50}\left(\mathrm{~mol} \cdot \mathrm{kg}^{-1}\right)$ of amylin as mean \pm SEM. All peptide antagonists were constantly infused $\left(12 \mathrm{nmol} \cdot \mathrm{kg}^{-1} \cdot \mathrm{min}^{-1}\right.$ i.v. $)$. In some cases animals were ganglion blocked (mecamylamine $3 \mathrm{mg} \cdot \mathrm{kg}^{-1}$ and atropine $400 \mathrm{mg} \cdot \mathrm{kg}^{-1} \mathrm{~s}$. c.) or ganglion blocked and infused with phenylephrine $\left(60 \mathrm{nmol} \cdot \mathrm{kg}^{-1} \cdot \mathrm{min}^{-1}\right)$. Some animals received the ACE-inhibitor, ramiprilat $\left(300 \mathrm{nmol} \cdot \mathrm{kg}^{-1}\right.$ s.c. $)$. Agonists were added in i.v. bolus concentrations. All estimates were from $6-8$ animals. ${ }^{\text {a }} \mathrm{p}<0.05$ vs control

Table 2. Effects of agonists on plasma renin activity in the anaesthetised rat

\begin{tabular}{lcll}
\hline & $\mathrm{n}$ & Baseline & Post-injection \\
\hline Vehicle & 4 & $2.8 \pm 0.9$ & $2.4 \pm 0.8$ \\
$\begin{array}{l}\text { Amylin } \\
(1 \mathrm{nmol} / \mathrm{kg})\end{array}$ & 5 & $2.4 \pm 0.5$ & $4.4 \pm 1.2^{\mathrm{a}}$ \\
$\begin{array}{l}\text { Salmon calcitonin } \\
(1 \mathrm{nmol} / \mathrm{kg})\end{array}$ & 4 & $3.1 \pm 0.9$ & $4.5 \pm 1.3$ \\
\hline
\end{tabular}

Data are mean \pm SEM.

${ }^{a} p<0.05$ vs baseline. Data are shown for plasma renin activity as $\mathrm{ngA} 1 \cdot \mathrm{ml}^{-1} \cdot \mathrm{h}^{-1}$. Agonists were added in i.v. bolus concentrations

brain with similar affinity to amylin $[9,10]$. However, one cannot exclude that the effect of salmon calcitonin was via other calcitonin receptors which are present in the central nervous system [23].

Although CGRP can also bind to the putative amylin receptor, it has higher affinity to the CGRP receptor which has recently been cloned [24]. Therefore, in contrast to amylin, CGRP does not elicit a pressor response at low concentrations but acts as a vasodilator, leading to reduced blood pressure via these vascular CGRP receptors [5]. Amylin interacts at higher concentrations with the CGRP receptor $[6$, $8,25,26]$ and this would explain the hypotensive response of submicromolar concentrations of amylin which were attenuated by $\mathrm{CGRP}_{8-37}$ (Table 1 ). In contrast, the putative amylin-selective antagonist, AC413, does not affect the hypotensive response to amylin, consistent with this antagonist's low affinity for vascular CGRP-receptors.

Since high affinity salmon calcitonin- and amylinselective binding sites have been identified in the rat brain $[10,11,23,27]$ and blood-borne salmon calcitonin can interact with specific sites in the rat brain $[27,28]$, it is possible that, at concentrations below those which activate vascular CGRP receptors, amylin may act at a central site to elicit its pressor effect. This hypothesis is consistent with our finding that the pressor responses to amylin were attenuated by ganglion blockade. Since ganglion blockade reduced MAP, and reduced renal perfusion pressure may stimulate renin release [29] thereby confounding the effects of amylin on the renin-angiotensin system, we evaluated the effects of amylin in ganglionblocked animals with raised vascular tone. In this group of animals amylin did not elicit pressor responses, but the amylin-induced hypotension was markedly enhanced. Although it is possible that, in these animals, the enhanced hypotensive effect of amylin masked the pressor effect of amylin we think it more likely that ganglion blockade directly attenuated the pressor response to amylin since the pressor effect was abolished in both ganglion-blocked and ganglion-blocked with raised vascular tone groups. As yet we have no explanation for the potentiation of the amylin-mediated depressor response following the elevation of vascular tone with phenylephrine.

Our finding that the pressor effects of amylin and of salmon calcitonin were blocked by the ACE inhibitor, ramiprilat, indicates that the pressor effect of these peptides is dependent upon a functional reninangiotensin system. This hypothesis is consistent with reports of elevated plasma renin activity in man and in rats following peripheral $[12,14,15,30]$ or central administration [30] of either of these peptides. In the present study, one cannot determine if the effect of amylin was via effects on the renin-angiotensin system at the central, systemic or renal level. We have confirmed that amylin will stimulate PRA in anaesthetised rats (Table 2) as has been previously documented [31]. These findings complement the results that our group has obtained in conscious rats [15]. Salmon calcitonin has also been previously reported to have an effect on PRA in rats [30]. Our evidence of an amylin-mediated increase in PRA is also consistent with a proposed mechanism of action of amylin in hyperamylinaemic states such as the insulin resistance syndrome [32-34].

It has previously been shown that amylin is co-secreted with insulin [35] and that hyperinsulinaemic states are associated with hyperamylinaemia [36]. In various animal models of insulin resistance including rodents with obesity, glucose intolerance and hypertension, amylin concentrations have been reported to be markedly elevated in the subnanomolar range $[37,38]$. Further evidence to indicate a role for amylin in the genesis of obesity-related hypertension has been suggested by the preliminary report in the sucrose-fed rat [39]. In these animals, the amylin antagonist, AC413, prevented the rise in blood pressure. This peptide antagonist has been reported by our 
group to prevent amylin-induced increases in PRA [15] and in the present study was shown to attenuate the acute pressor response of amylin in the anaesthetised rat.

One must be cautious in extrapolating these results in rats to the role of amylin in man. Nevertheless, plasma amylin levels are elevated in individuals with essential hypertension [40]. Amylin has been reported to increase plasma renin concentrations in man [12] and more recent studies have indicated that this effect of amylin on renin occurs within the pathophysiological range [31]. Although blood pressure was not a major endpoint in our previous study on the effects of amylin in man, it is of interest that the amylin infusion was associated with a modest increase in blood pressure [12].

From the present study, one cannot assume that these modest effects of amylin on systemic blood pressure would ultimately translate to the development of essential hypertension. The potential impact of only modest changes in blood pressure on the ultimate development of essential hypertension has been extensively investigated by Lever et al. [41] using subpressor doses of angiotensin II. Despite minimal acute effect on blood pressure, these subpressor doses of angiotensin II ultimately led to chronic hypertension. To explore the possibility of a similar effect of amylin, more chronic studies are required which will involve achieving amylin levels in the range that would elicit a pressor response rather than studies with higher amylin levels which could decrease blood pressure via a lower affinity interaction with CGRP receptors. Plasma amylin levels in pathophysiological states [36] are within the range which would elicit a pressor rather than a hypotensive response, consistent with the hypothesis that in the pathophysiological context amylin tends to raise rather than reduce blood pressure. It is of interest that the only report of a patient with an amylin-secreting pancreatic islet cell tumour indicated that the patient had hypertension [42]. In contrast, patients with insulinomas do not have elevated blood pressure [43]. This provides further evidence for amylin rather than insulin being responsible for the hypertension associated with hyperinsulinaemic/hyperamylinaemic states.

In conclusion, we have shown that both amylin and salmon calcitonin, an agonist of the amylin receptor [9], elicit pressor responses in the anaesthetised rat. Since the pressor response to amylin is blocked by peptide antagonists and is abolished by ganglion blockade we conclude that amylin acts at a receptor in the central nervous system. It is postulated that stimulation of a central amylin receptor leads to increased systemic blood pressure, possibly through the stimulation of the renin-angiotensin system. Furthermore, it is suggested that these modest effects in raising blood pressure could ultimately lead to the development of hypertension in states of chronic hyperinsulinaemia/hyperamylinaemia.

A cknowledgements. Ethical approval for these experiments was obtained from the Heidelberg Repatriation Hospital ethics committee. This study was supported with grants from the Rebecca L. Cooper Foundation and the Australian Kidney Foundation. We are grateful to Amylin Pharmaceuticals for the provision of various peptides including amylin receptor antagonists.

\section{References}

1. Cooper GJS, Willis AC, Clark A, Turner RC, Sim RB, Reid KBM (1987) Purification and characterization of a peptide from amyloid rich pancreases of type 2 diabetic patients. Proc Nat Acad Sci 84: 8628-8632

2. Westermark P, Johnson KH, O'Brien TD, Betsholtz C (1992) Islet amyloid polypeptide - a novel controversy in diabetes research. Diabetologia 35: 297-303

3. Bennet WM, Beis CS, Ghatei MA, Byfield PG, Bloom SR (1994) Amylin tonally regulates arginine-stimulated insulin secretion in rats. Diabetologia 37: 436-438

4. Young AA, Gedulin B, Wolfe-Lopez D, Greene HE, Rink TJ, Cooper GJS (1992) Amylin and insulin in rat soleus muscle: dose response for cosecreted noncompetitive antagonists. Am J Physiol 263:E274-E281

5. Haynes JM, Cooper ME (1995) Adrenomedullin and calcitonin gene-related peptide in the rat isolated kidney and in the anaesthetised rat: in vitro and in vivo effects. Eur J Pharmacol 280: 91-94

6. Gardiner SM, Compton AM, Kemp PA et al. (1991) Antagonistic effect of human alpha-calcitonin gene-related peptide (8-37) on regional hemodynamic actions of rat islet amyloid polypeptide in conscious Long-Evans rats. Diabetes 40: 948-951

7. Fujioka S, Sasakawa O, Kishimoto H, Tsumura K, Morii H (1991) The antihypertensive effect of calcitonin gene-related peptide in rats with norepinephrine- and angiotensin II-induced hypertension. J Hypertens 9: 175-179

8. Abdelrahman A, Wang YX, Chang SD, Pang CC (1992) Mechanism of the vasodilator action of calcitonin generelated peptide in conscious rats. Br J Pharmacol 106: 4548

9. Sexton PM, Paxinos G, Kenney MA, Wookey PJ, Beaumont K (1994) In vitro autoradiographic localization of amylin binding sites in rat brain. Neuroscience 62: 553-567

10. Beaumont K, Kenney MA, Young AA, Rink TJ (1993) High affinity amylin binding sites in rat brain. Mol Pharmacol 44: 493-497

11. Van Rossum D, Menard DP, Fournier A, St Pierre S, Quirion R (1994) Autoradiographic distribution and receptor binding profile of $\left[{ }^{125} \mathrm{I}\right]$ Bolton Hunter-rat amylin binding sites in the rat brain. J Pharmacol Exp Ther 270: 779-787

12. Cooper ME, McNally PG, Phillips PA, Johnston CI (1995) Amylin stimulates plasma renin concentration in humans. Hypertension 26: 460-464

13. Kurtz A, Muff R, Born W et al. (1988) Calcitonin gene-related peptide is a stimulator of renin secretion. J Clin Invest 82: 538-543

14. Fiore CE, Mazzarino MC, Malatino L, Malponte G, Foti R, Guzzardi F (1983) Salmon calcitonin activity and plasma renin activity in man. Miner Metab Res 4: 165-167

15. Wookey PJ, Tikellis C, Du H-C, Qin H-F, Sexton PM, Cooper ME (1996) Amylin binding in rat renal cortex, 
stimulation of adenylyl cyclase and activation of plasma renin. Am J Physiol 270:F289-F294

16. Young AA, Carlo P, Rink TJ, Wang MW (1992) 8-37hCG$\mathrm{RP}$, an amylin receptor antagonist, enhances the insulin response and perturbs the glucose response to infused arginine in anesthetized rats. Mol Cell Endocrinol 84:R1-R5

17. Mendelsohn FAO, Hutchinson J, Johnston CI (1971) A review of plasma renin measurements and their clinical significance. Aust NZ J Med 1: 86-93

18. McMahon EG, Palomo MA, Moore WM (1991) Phosphoramidon blocks the pressor activity of big endothelin[139] and lowers blood pressure in spontaneously hypertensive rats. J Cardiovasc Pharmacol 17: [Suppl 7] S29-S33

19. Olins GM, Smits GJ, Koepke JP et al. (1993) In vivo pharmacology of SC-51316, a nonpeptidic angiotensin II receptor antagonist. Am J Hypertens 6: 619-625

20. Komers R, Cooper ME (1995) Acute renal haemodynamic effects of angiotensin converting enyzme inhibition in diabetic hyperfiltration: the role of kinins. Am J Physiol 268:F588-F594

21. Guardabasso V, Rodbard D, Munson PJ (1987) A modelfree approach to estimation of relative potency in dose-response curve analysis. Am J Physiol 252:E357-E364

22. Guardabasso V, Munson PJ, Rodbard D (1988) A versatile method for simultaneous analysis of families of curves. FASEB J 2: 209-215

23. Sexton PM, McKenzie JS, Mendelsohn FAO (1988) Evidence for a new subclass of calcitonin/calcitonin gene-related peptide binding sites in rat brain. Neurochem Int 12: 323-335

24. Kapas S, Clark AJ (1995) Identification of an orphan receptor gene as a type 1 calcitonin gene-related peptide receptor. Biochem Biophys Res Commun 217: 832-838

25. Young AA, Rink TJ, Wang MW (1993) Dose response characteristics for the hyperglycemic, hyperlactemic, hypotensive and hypocalcemic actions of amylin and calcitonin gene-related peptide-I (CGRP alpha) in the fasted, anaesthetized rat. Life Sci 52: 1717-1726

26. Morishita T, Yamaguchi A, Fujita T, Chiba T (1990) Activation of adenylate cyclase by islet amyloid polypeptide with $\mathrm{COOH}$-terminal amide via calcitonin gene-related peptide receptors on rat liver plasma membranes. Diabetes 39: $875-877$

27. Van Houten M, Rizzo AJ, Goltzman D, Posner BI (1982) Brain receptors for blood-borne calcitonin in rats: circumventricular localization and vasopressin-resistant deficiency in hereditary diabetes insipidus. Endocrinology 111 : 1704-1710
28. Rouleau MF, Warshawsky H, Goltzman D (1984) Specific receptors for calcitonin in the subfornical organ of the brain. Brain 107: 107-114

29. Scholz H, Vogel U, Kurtz A (1993) Interrelation between baroreceptor and macula densa mechanisms in the control of renin secretion. J Physiol Lond 469: 511-524

30. Clementi G, Rapisarda E, Fiore CE et al. (1986) Effects of salmon calcitonin on plasma renin activity and systolic blood pressure in the rat. Neurosci Lett 66: 351-355

31. Young AA, Nuttall A, Moyses C, Percy A, Vine W, Rink T (1995) Amylin stimulates the renin-angiotensin-aldosterone axis in rats and man. Diabetologia 38 [Suppl 1]:A225 (Abstract)

32. Williams B (1994) Insulin resistance: the shape of things to come. Lancet 344: 521-524

33. Young AA, Rink TJ, Vine W, Gedulin B (1994) Amylin and syndrome-X. Drug Develop Res 32: 90-99

34. Sandler S (1994) The biological role of islet amyloid polypeptide (amylin) in diabetes: some recent results. 37: 225-266

35. Kahn SE, D'Alessio DA, Schwartz MW et al. (1990) Evidence of cosecretion of islet amyloid polypeptide and insulin by beta-cells. Diabetes 39: 634-638

36. Cooper GJ (1994) Amylin compared with calcitonin generelated peptide: structure, biology, and relevance to metabolic disease. Endocrine Rev 15: 163-201

37. Gill AM, Yen TT (1991) Effects of ciglitazone on endogenous plasma islet amyloid polypeptide and insulin sensitivity in obese-diabetic viable yellow mice. Life Sci 48: 703710

38. Huang CL, Ives HE, Cogan MG (1986) In vivo evidence that cGMP serves as the second messenger for atrial natriuretic factor. Proc Natl Acad Sci (USA) 83: 8015-8018

39. Bhaysar S, Young A (1995) The selective amylin antagonist, AC413, prevents sucrose-induced increases in mean arterial pressure in rats. Am J Hypertens 8: 55A

40. Kautzky-Willer A, Thomaseth K, Pacini G et al. (1994) Role of islet amyloid polypeptide secretion in insulin-resistant humans. Diabetologia 37: 188-194

41. Lever AF (1993) Slow developing pressor effect of angiotensin II and vascular structure. J Hypertens Suppl 11: S27-S28

42. Stridsberg M, Wilander E, Oberg K, Lundqvist G, Eriksson B (1992) Islet amyloid polypeptide-producing pancreatic islet cell tumor. A clinical and biochemical characterization. Scand J Gastroenterol 27: 381-387

43. Sawicki PT, Heinemann L, Starke A, Berger M (1992) Hyperinsulinaemia is not linked with blood pressure elevation in patients with insulinoma. Diabetologia 35: 649-652 